\title{
NILAI-NILAI KEPEMIMPINAN ISLAM DALAM BERKELUARGA SEBAGAI TOLAK UKUR MENDASAR (BASE ON) INTEGRITAS CALON LEGISLATIF
}

\section{TUTI RASTUTI}

Dosen Fakultas Hukum Universitas Pasundan, Jl. Lengkong Besar No. 68 Bandung 40261, Telp: 0224262226, Fax: 022-4217340, Hp: 0818647356 , E-mail: rush_2_t@yahoo.com.

\begin{abstract}
ABSTRAK
Mempersiapkan pemimpin yang berintegritas diproses pembinaannya dari keluarga. Berbagai cara dilakukan oleh negara untuk menentukan calon pemimpin, baik melalui regenerasi pengkaderan, penunjukan ataupun pemilihan. Pemilu merupakan sarana untuk mengolah dan menentukan siapa yang akan memimpin dan memegang amanah rakyat yang dipimpinnya. Pemilu merupakan proses, namun hakikat menentukan pemimpin harus dilihat dari kualitas kepribadiannya. Masyarakat sering dihadapkan pada dilema sosok pemimpin bagaimanakah yang baik? Nilai-Nilai kepemimpinan Islam dalam berkeluarga akan menjawab apa dan bagaimana pemimpin yang memiliki integritas tinggi. Sebab, keluarga merupakan miniatur unit terkecil dari suatu komunitas. Pemimpin yang berintegrasi adalah pemimpin yang memiliki komitmen terhadap keluarganya. Pemimpin umat dalam skala yang besar ditentukan oleh kepemimpinannya dalam skala kecil yaitu pemimpin yang menerapkan nilai-nilai Islam dalam berkeluarga.
\end{abstract}

Kata Kunci: Nilai Islam, Keluarga, Kepemimpinan, Legislatif.

\begin{abstract}
Prepare leaders with integrity processed fostering of the family. Various methods are used to determine the state 's future leaders, both through the regeneration of the cadre, the appointment or election. Election is a means to process and determine who will lead and hold the mandate of the people they lead. Election is a process, but the nature of the leader determines to be seen from the quality of his personality. Communities are often faced with the dilemma of how good a leader ? $V$ alues of the Islamic leadership in the family will answer what and how a leader with high integrity. Therefore, the family is the smallest unit of a miniature community. Integration leader is a leader who has a commitment to his family. The leader of the ummah in a large scale is determined by its leadership in the small-scale leader applying Islamic values in the family.
\end{abstract}

Keywords : Islamic Values, Family, Leadership, Legislative. 


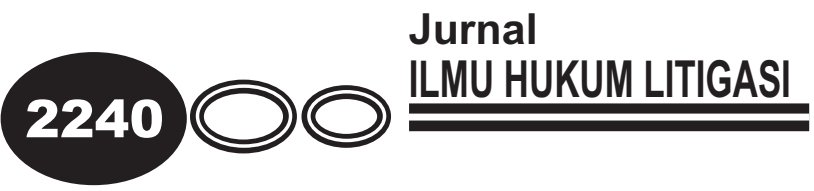

\section{PENDAHULUAN}

Menjelang pemilihan umum April 2014, masyarakat dihadapkan pada dilema sosok calon legislatif yang akan dipilihnya. Hal ini mengingat banyak kasus hukum yang menyeruak sehubungan dengan elit-elit politik yang dinilai masyarakat melanggar norma susila, norma sosial, dan norma hukum. Pertanyaan dibenak masyarakat pemilih adalah (1) siapa calon yang dapat mengaspirasikan kepentingannya sebagai anggota masyarakat, kepentingan bangsa, dan kepentingan negara, dan yang menyelamatkan dunia dan akhiratnya suatu kaum, (2) bagaimana integritas moral dan akhlaknya, apakah caleg tersebut amanah, lurus dalam perkataan, hati dan perbuatannya, (3) apakah ukuran persyaratan yang dimintakan KPU menjamin integritas moral spiritual , akhlak, nalar dan kepribadian. Syarat administratif yang harus dipenuhi untuk menjadi calon legislatif bukan persoalan utama bagi masyarakat pemilih, mungkin menjadi terbalik bahwa syarat formal akan menjadi syarat tambahan bagi masyarakat dalam menentukan pilihan, syarat materiil yang dibutuhkan oleh masyarakat terhadap calon legislatifnya adalah integritas moral spiritual, akhlak, nalar dan kepribadian menjadi syarat utama. Fokus utama yang menjadi pijakan atau rujukan penyelesaian masalah adalah, "Nilai-nilai apa yang harus dimiliki oleh para caleg, sebagai calon pemimpin bangsa". Beberapa ciri yang dimiliki oleh pemimpin yang baik akan dijadikan faktor ketika menilai orangorang yang akan dipersiapkan sebagai calon legislatif, calon yang dipilih paling sedikit memiliki 3 (tiga) ciri (W.A. Garungan,1967:138), yaitu: (1) Persepsi sosial; yakni 
kecakapan dalam melihat dan memahami perasaan, sikap dan perilaku orang lain/masyarakat. Dengan kata lain, memiliki kecakapan bagaimana menempatkan dan memahami orang lain; (2) Kemampuan berfikir abstrak; yakni kemampuan untuk membaca fenomena yang bakal terjadi. Dengan kata lain memiliki kemampuan untuk melihat apa yang akan terjadi dimasa yang akan datang. (3) Keseimbangan emosional; yaitu mereka yang mempunyai pandangan positif (husnuzzhon) terhadap orang lain atau yang memiliki perasaan seimbang dalam melihat sesuatu. Dengan demikian proses penentuan pilihan, lebih kepada penilaian bagaimana menemukan calon legislatif sebagai pemimpin yang unggul dari dimensi kapabilitas, kredibilitas, dan akseptabilitas (http://berkarya.um.ac.id).

Menyikapi persoalan calon legislatif sebagai calon pemimpin, tak dapat dipisahkan dari bagaimana memimpin keluarganya. Sebab, keluarga merupakan miniatur kepemimpinan dari sebuah komunitas yang lebih besar, yaitu komunitas memimpin bangsa atau umat. Artinya, dimensi kapabilitas, kredibilitas, dan akseptabilitas calon legislatif tersebut dapat dilihat dari sikap, perbuatan dan karakter dalam memperlakukan keluarganya dalam kesehariannya.

Menyikapi kepemimpinan dalam Islam, maka pedoman bagi calon legislatif dalam menentukan visi dan misi, dan aktualitas diri khususnya bagi yang muslim adalah Al-qur'an dan Hadist. Namun demikian, Al-Qur'an dan Hadist bukan hanya milik kaum muslim. Sebab, Agama Islam adalah agama Rahmattan lil allamin. Sumber hukum Islam yaitu Al-Qur'an dan Hadist dapat menuntun semua golongan, bangsa 


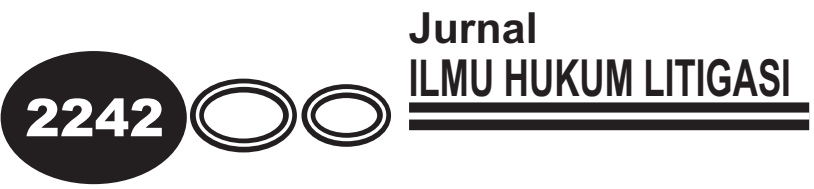

dan negara untuk keselamatan dunia dan akhiratnya, baik bagi dirinya sendiri, juga keselamatan rakyat yang dipimpinnya. Dengan demikian apabila nilai-nilai dalam kepemimpinan Islam dalam berkeluarga dijadikan oleh para elit politik, calon legislatif, atau yang sudah menjadi legislatif ditegakkan, diyakini bahwa negara Indonesia akan terbebas dari kemelut komitmen politik yang ewuh pakewuh, politik wani piro, komitmen politik yang menyebabkan seorang elit politik menjadi tinggi hati, sombong, ria takabur, dan tidak memiliki jati diri, tetapi menjadikan elit politik, calon legislatif yang memiliki integritas moral spiritual, berakhlak, nalar dan berkepribadian. Adapun permasalahan yang akan dibahas adalah bagaimana nilai-nilai kepemimpinan Islam dalam berkeluarga sebagai acuan integritas calon legislatif, bagaimana sikap cerdas masyarakat pemilih terhadap calon pemimpin yang tidak berkomitmen kepada keluarga.

\section{PEMBAHASAN}

A. Nilai-Nilai Kepemimpinan Islam dalam Berkeluarga Sebagai Acuan lintegritas Calon Legislatif

1. Pemimpin dan Kepemimpin yang Berkepribadian Islam

Pemimpin dan Kepemimpinan merupakan dua elemen yang saling berkaitan. Artinya, kepemimpinan (style of the leader) merupakan cerminan dari karakter/perilaku subjek pemimpin tersebut (leader behavior). Perpaduan (sintesis) antara "leader behavior dengan leader 
style" merupakan kunci keberhasilan pengelolaan suatu organisasi (http://berkarya pemimpinan-dan-kepemimpinan-menurut-islam/). Pengelolaan organisasi yang paling sederhana dan alamiah adalah organisasi keluarga, dalam skala yang lebih luas adalah pengelolaan daerah atau wilayah, dan bahkan negara. Pemimpin (leader) merupakan status yang disandang seseorang karena menjadi kepala keluarga, ketua organisasi atau institusi, direktur, atau manajer, dan sebagainya pada suatu organisasi atau lembaga, sedangkan kepemimpinan (leadership) lebih merupakan tindakan dan perilaku yang ditampilkan ketika berinteraksi dengan orang lain, baik antara sesama pemimpin maupun dengan bawahan. Hubungan interaksi antara imam dan ma'mum.

Terdapat banyak pengertian mengenai kepemimpinan ini menurut para ahli (R. Terry. George, 2006:495), namun semuanya mengarah kepada suatu tugas utama pemimpin yaitu bagaimana agar ia dapat menguasai dan mempengaruhi orang lain secara efektif (Effendi, 1992 : 2).

Kepemimpinan Islam adalah kepemimpinan yang berdasarkan hukum Allah (http://berkarya/pemimpinan-dan-kepemimpinan-menurutislam/). Oleh karena itu, pemimpin haruslah orang yang sarat dengan pengetahuan tentang hukum Illahi, aktivitas kesehariannya berpedoman kepada hukum Illahi dalam bentuk aktualitas diri, dan memiliki komitmen 


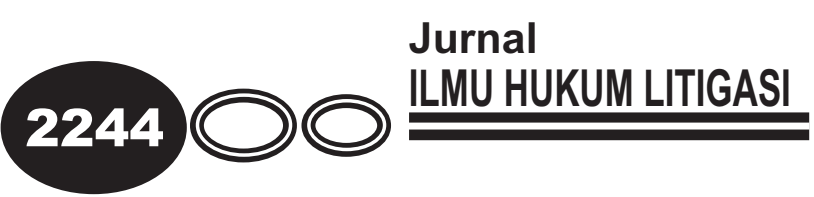

tanggung jawab, dengan jaminan menyelamatkan kaum/bangsa baik di dunia maupun di akhirat.

Perlu dikaji ayat Al-Qur’an berkaitan dengan kepemimpinan (imam) dalam berkeluarga dan berbangsa.

1. Q.S. at-Tahrim: 6

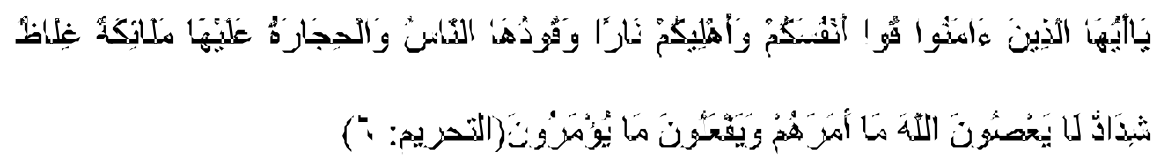

Hai orang-orang yang beriman, peliharalah dirimu dan keluargamu dari api neraka yang bahan bakarnya adalah manusia dan batu; penjaganya malaikat-malaikat yang kasar, yang keras, yang tidak mendurhakai Allah terhadap apa yang diperintahkanNya dan selalu mengerjakan apa yang diperintahkan-Nya. Dalam ayat 6 Surat AtTahrim ini, Allah memerintahkan kita untuk dapat menjaga tidak hanya diri sendiri tetapi juga diri dan keluarga dari perbuatanperbuatan yang dapat menjerumuskan ke dalam siksa api neraka. Selain menjaga diri sendiri, kitapun diperintahkan untuk menasihati dan memberikan pengajaran terhadap keluarga kita untuk senantiasa taat dan menjalankan segala perintah Allah yang pada akhirnya dapat menjauhkan dari siksa neraka. Kategori yang termasuk ke dalam keluarga dalam ayat ini adalah istri, anak, dan orang lain yang berada dibawah tanggungan kita seperti kerabat yang tinggal di rumahnya, 
pembantu dan sopir. Dengan demikian, begitu erat diri kita dengan anggota keluarga dalam tanggung jawab, dan saling menyelamatkan.

2. Q.S. an-Nisa: 9

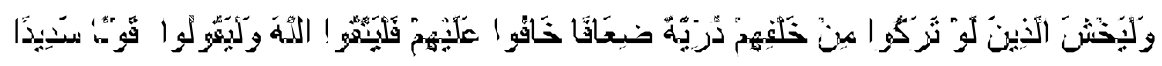
( الأنساء: (9)

Dan hendaklah takut kepada Allah orang-orang yang seandainya meninggalkan di belakang mereka anak-anak (keturunan) yang lemah, yang mereka khawatir terhadap (kesejahteraan) mereka. Oleh sebab itu, hendaklah mereka bertakwa kepada Allah dan hendaklah mereka, mengucapkan perkataan yang benar. Ayat 9 di atas menjelaskan fungsi keluarga, yaitu menjaga kelangsungan hidup keluarga dari kepunahan dengan cara menyiapkan generasi penerus yang lebih kuat, baik fisik maupun mentalnya. Dari segi fisik, mereka harus dibekali dengan makanan dan minuman yang bergizi, selain sandang, pangan dan perumahan yang memadai, sedangkan dari segi mental, mereka harus dibekali dengan pendidikan agama yang dapat menuntun mereka kepada jalan yang benar. Akhir ayat itu pun menganjurkan kepada para orang tua untuk memperlakukan semua anggota keluarganya dengan tegur sapa atau ucapan-ucapan yang baik yang menunjukkan sikap kasih sayang dan mendidik. 


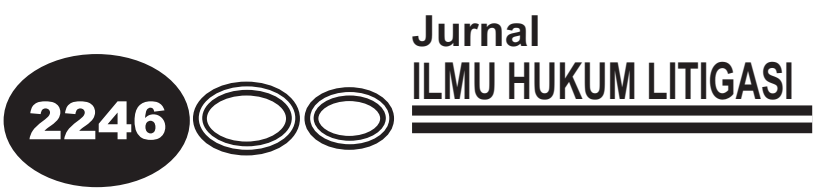

3. Q.S. Thaha : 132

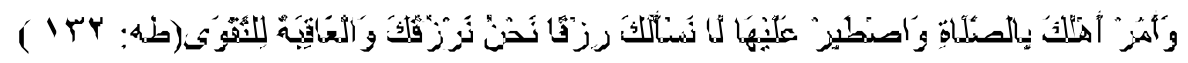
Dan perintahkanlah kepada keluargamu untuk mendirikan shalat dan bersabarlah kamu dalam mengerjakannya. Kami tidak meminta rezeki kepadamu, Kamilah yang memberi rezeki kepadamu. Dan akibat (yang baik) itu adalah bagi orang-orang yang bertakwa.

Ayat 132 di atas, menjelaskan bahwa salah satu kewajiban kepala keluarga adalah memerintahkan anggota keluarganya untuk melaksanakan dan memelihara shalat dengan baik. Perintah melaksanakan shalat ini disampaikan kepada anak-anaknya ketika mereka mulai menginjak usia tujuh tahun seperti termuat dalam hadits :

4. Al-Hadis

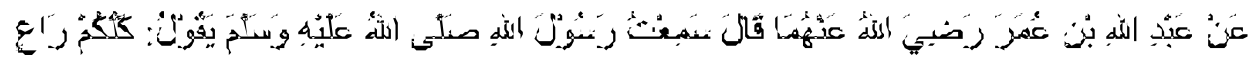

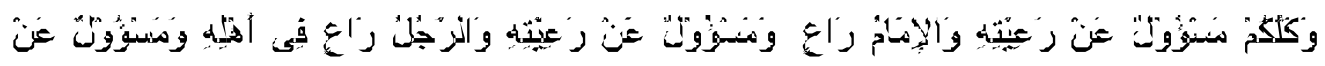

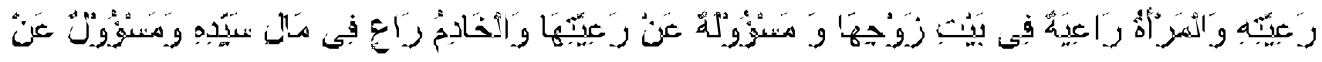

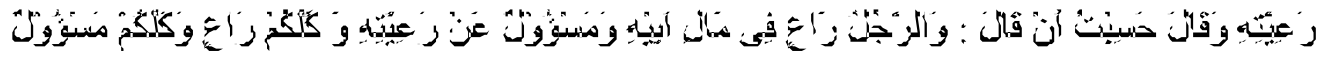

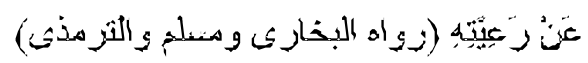

Dari Abdullah bin Umar ra. ia berkata : Saya mendengar Rasulullah saw. bersabda : "Setiap kamu adalah pemimpin dan bertanggung jawab atas apa yang dipimpinnya. Imam adalah pemimpin dan bertanggung jawab atas rakyatnya. Lelaki adalah pemimpin dalam keluarganya dan 
bertanggung jawab atas anggota keluarganya. Dan seorang perempuan adalah pemimpin dalam rumah tangga suaminya, dan ia bertanggung jawab atas semua anggota keluarganya. Seorang pembantu adalah pemimpin bagi harta majikannya, dan ia bertanggung jawab atas keselamatan dan keutuhan hartanya". Abdullah berkata : 'Aku mengira Rasulullah mengatakan pula bahwa seseorang adalah pemimpin bagi harta ayahnya dan bertanggung jawab atas keselamatan dan keutuhan hartanya itu. Semua kamu adalah pemimpin dan bertanggung jawab atas segala yang dipimpinnya (HR. Bukhari Muslim dan Turmudzi).

Dalam Islam, figur pemimpin ideal yang menjadi contoh dan suri teladan yang baik, bahkan menjadi rahmat bagi manusia (rahmatan linnas) dan rahmat bagi alam (rahmatan lil'alamin) adalah Rasulullah Saw., sebagaimana dalam firman-Nya :

"Sesungguhnya telah ada pada (diri) Rasulullah itu suri teladan yang baik bagimu (yaitu) bagi orang yang mengharap (rahmat) Allah dan (kedatangan) hari kiamat dan dia banyak menyebut Allah."

Dalam QS.al-Ahzab [33]: 21, yang makna diartikan sebagai berikut: Sebenarnya, setiap manusia adalah pemimpin, minimal pemimpin terhadap seluruh metafisik dirinya. Dan setiap pemimpin akan dimintai pertanggungjawaban atas segala kepemimpinannya. 


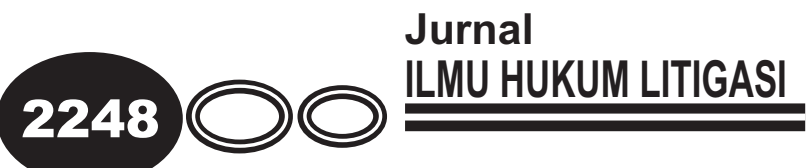

Kemudian dalam Islam, seorang pemimpin yang baik adalah pemimpin yang memiliki sekurang-kurangnya 4 (empat) sifat dalam menjalankan kepemimpinannya, yakni : Siddiq, Tabligh, Amanah dan Fathanah (STAF): (1) Siddiq (jujur) sehingga ia dapat dipercaya; (2) Tabligh (penyampai) atau kemampuan berkomunikasi, bermusyawarah dan bernegosiasi, ; (3) Amanah (bertanggungjawab) dalam menjalankan tugasnya, bertanggungjawab untuk membawa yang dipimpinnya selamat dunia dan akhirat; (4) Fathanah (cerdas) dalam membuat perencanaan, visi, misi, strategi dan mengimplementasikannya.

Selain itu, juga dikenal ciri pemimpin Islam (Al-Hadist): “Pemimpin suatu kelompok adalah pelayan kelompok tersebut." Oleh sebab itu, pemimpin hendaklah ia melayani dan bukan dilayani, serta menolong orang lain untuk maju.

Perkembangan selanjutnya, terdapat beberapa ciri penting untuk menggambarkan kepemimpinan Islam yaitu : Pertama, setia kepada Allah. Pemimpin dan orang yang dipimpin terikat dengan kesetiaan kepada Allah; Kedua, tujuan Islamnya secara menyeluruh. Pemimpin melihat tujuan wadah/institusi bukan saja berdasarkan kepentingan kelompok, tetapi meliputi ruang lingkup kepentingan Islam yang dimulai dari unit terkecil yaitu kepentingan keluarganya sampai pada lebih luas yaitu umat/bangsa; Ketiga, berpegang pada syariat dan 
akhlak Islam. Pemimpin terikat dengan peraturan Islam, dan boleh menjadi pemimpin selama ia berpegang teguh pada perintah syariah. Dalam mengendalikan urusannya ia harus patuh kepada adab-adab (attitude) Islam, khususnya ketika berurusan dengan golongan oposisi atau orang-orang yang tak sepaham; Keempat, pengemban amanat. Pemimpin menerima kekuasaan sebagai amanah dari Allah SWT, yang disertai oleh tanggung jawab yang besar. Al-Quran memerintahkan pemimpin melaksanakan tugasnya untuk Allah dan menunjukkan sikap yang baik kepada pengikut atau bawahannya karena Allah (Hisham Yahya Altalib, 1991:55).

Allah SWT berfirman : “(yaitu) orang-orang yang jika kami teguhkan kedudukkan mereka di muka bumi niscaya mereka mendirikan shalat, menunaikan zakat, menyuruh berbuat ma'ruf dan mencegah dari perbuatan yang mungkar; dan kepada Allah-lah kembali segala urusan." (QS. al-Hajj [22]:41).

Hal lain yang perlu diperhatikan adalah adanya prinsip-prinsip dasar dalam kepemimpinan Islam meliputi (1) Musyawarah; (2) Keadilan; dan (3) Kebebasan berfikir. Pemimpin Islam bukanlah kepemimpinan tirani dan tanpa koordinasi. (http://salam-online.com). Namun, pola pikir, pola perilaku, dan pola pemahamannya yang mendasari dirinya adalah prinsipprinsip Islam. Pengambilan keputusan dan tindakan memimpinnya apabila 


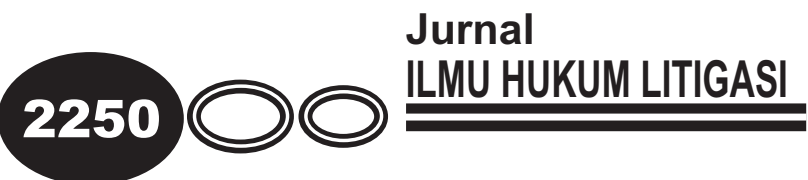

dipandang perlu bermusyawarah dengan anggota keluarga dan sahabatsahabatnya secara obyektif dan dengan penuh rasa hormat, membuat keputusan seadil-adilnya, dan berjuang menciptakan kebebasan berfikir, pertukaran gagasan yang sehat dan bebas, saling kritik dan saling menasihati satu sama lain dalam kebaikan dan kebenaran sedemikian rupa, sehingga para pengikut atau bawahan merasa senang mendiskusikan persoalan yang menjadi kepentingan dan tujuan bersama, saling memotivasi dan berkonsolidasi. Pemimpin Islam bertanggung jawab bukan hanya kepada pengikut atau bawahannya semata, tetapi yang jauh lebih penting adalah tanggungjawabnya kepada Allah SWT selaku pengemban amanah kepemimpinan. Kemudian perlu dipahami bahwa seorang muslim yang amanah adalah pemimpin yang dalam kapasitasnya masing-masing wajib memberikan nasihat apabila diperlukan, sebagaimana Hadits Nabi dari: Tamim bin Aws meriwayatkan bahwasanya Rasulullah SAW pernah bersabda:

"Agama adalah nasihat." Kami berkata: "Kepada siapa?” Beliau menjawab: “Kepada Allah, Kitab-Nya, Rasul-Nya, Pemimpin umat Islam dan kepada masyarakat kamu."

Hadist Imam Muslim meriwayat, Rasulullah berseru, "wahai manusia, sesungguhnya aku ini manusia yang hampir didatangi oleh utusan Tuhanku, maka akupun menghadap - Nya. Sesungguhnya aku tinggalkan 
padamu dua perkara yang amat berharga, pertama adalah kitab Allah, yang merupakan tali Allah, dan ahlul baith. Barangsiapa yang mengikutinya maka dia berada di atas petunjuk, dan barang siapa yang meninggalnya maka ia berada di atas kesesatan."

Dalam riwayat tersebut, Rasul menyebut keduanya (Al-Qur'an dan Ahlul Baitnya) sebagai Tsaqalain yakni sesuatu yang sangat berharga. Keduanya tidak akan pernah terpisah dan saling melengkapi. Rasulullah menjamin bahwa siapapun yang bersungguh-sungguh dan berpegang pada kedua tsaqal ini, maka tidak akan pernah mengalami kesesatan. Kemunduran dan penyimpangan kaum muslimin terjadi ketika mencoba memisahkan kedua tsaqal ini.

Ahlul baith yang dimaksud adalah keluarganya yang ditempatkan dalam kedudukan yang istimewa.

Katakan (hai Muhammad): "Aku tidak meminta upah apapun kepada kalian dalam dakwah ini, kecuali kecintaan kepada keluargaku." (Surat Asy-Syura:23).

Dalam ayat ini Allah swt menegaskan bahwa upah yang harus diberikan oleh umat kepada Rasulullah SAW dalam dakwahnya adalah kecintaan kepada "Keluarga Istimewa" beliau yang dalam surat Al-Ahzab: 33 menyebut sebagai "Ahlul bait". 


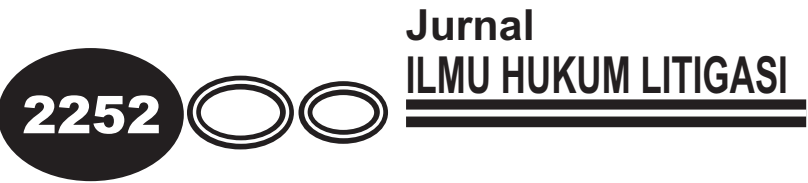

"Sungguh tiada lain Allah berkehendak menjaga kamu dari dosa-dosa hai Ahlul bait dan mensucikan kamu dengan sesuci-sucinya." (Al-Ahzab/33: 33)

2. Keluarga Sebagai Miniatur Pembinaan Kepemimpinan.

Keluarga merupakan sebuah pondasi dan institusi yang paling dicintai dalam Islam. Masyarakat terbentuk dari unit-unit yang lebih kecil dan keluarga merupakan unit yang paling sederhana dan alami, yang menjadi titik diawalinya kehidupan manusia. Keluarga adalah pusat perkumpulan dan pusat untuk melestarikan nilai-nilai, dalam keluargalah tempat untuk disemaikan kasih sayang dan emosional. Unit ini ibarat landasan sebuah komunitas dan ketahanannya akan mendorong ketangguhan sebuah masyarakat.

Tidak dapat dipungkiri bahwa sebagai institusi terkecil dalam masyarakat, keluarga memiliki pengaruh yang sangat besar terhadap keberhasilan pembangunan sebuah bangsa. Hal ini terkait erat dengan fungsi keluarga sebagai wahana pembentukan sumber daya manusia yang berkualitas. Keluarga memiliki peran fundamental dalam menjaga bangsabangsa dari dekadensi dan kehancuran. Ketentuan hukum harus disusun untuk mempermudah terbentuknya keluarga, memelihara kesuciannya, dan memperkuat hubungan kekeluargaan berdasarkan hak-hak dan etika Islam. Dari segi psikologi, keluarga juga punya peranan penting dalam 
meredam emosi, mencegah depresi, dan memberi dampak-dampak psikis lain bagi seseorang. Anak-anak yang kehilangan orang tuanya akan larut dalam kesedihan, diliputi rasa takut, bersikap emosi, dan kehilangan rasa tenang. Di sini terlihat kontribusi positif keluarga dalam menjaga kesehatan mental dan memberi ketahanan terhadap tekanan-tekanan jiwa dan depresi. Oleh karena itu, para pemimpin lahir dari unit terkecil yaitu keluarga, dalam pertumbuhannya sampai dan menjadi pemimpin umat (para elit politik, calon legislatif) integritasnya harus mengakar dari keluarga, seperti halnya sebuah pohon, jika akarnya kokoh maka pohonnya kokoh pula, dan buahnya (hasilnya) berkualitas pula. Dengan demikian kualitas suatu bangsa tidak terlepas dari keluarga unit terkecil. Integritas moral spiritual, akhlak, nalar dan kepribadian dapat dinilai dari bagaimana memperlakukan dan menempatkan anggota keluarga dalam unit terkecil yang sederhana dan alamiah tersebut. Bagaimana dapat memimpin umat yang begitu besar apabila sebagai elit politik, calon legislatif tidak dapat menempatkan keluarga dan memperlakukan keluarga dalam kedudukan yang istimewa, sebagaimana dititahkan Allah dan Rasulnya.

Rasulullah SAW bersabda, peliharalah kitab AI-Qur'an dan Ahlul Baitku. Rasul menyebut keduanya (Al-Qur'an dan Ahlul Baitnya) sebagai Tsaqalain yakni sesuatu yang sangat berharga. Demi Allah aku peringatkan kamu akan Ahlul Baitku, aku peringatkan kamu akan Ahlul Baitku, aku 


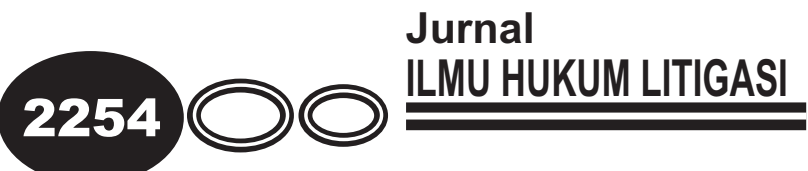

peringatkan kamu akan Ahlul Baitku. Begitu tegasnya Rasullulah dan begitu banyaknya kandungan di dalam Al-Qur'an yang turun berkaitan dengan keagungan keluarga Rasulullah yang mulia, begitu banyak kisah yang kita ketahui tentang Rasulullah yang selalu mengingatkan umatnya akan pengutamaan Allah atas keluarganya (http://indonesian.irib.ir/artikel1/).

Rasulullah menjamin bahwa siapapun yang bersungguh-sungguh dan berpegang pada kedua hal ini, maka tidak akan pernah mengalami kesesatan. Kemunduran dan penyimpangan kaum muslimin terjadi ketika mencoba memisahkan kedua hal ini.

Perlu dikritisi bahwa, kelestarian generasi umat manusia tergantung pada eksistensi keluarga yang dibangun atas dasar mawaddah dan rahmah. Dengan melemahnya pilar-pilar keluarga, misalnya masyarakat yang terdiri dari individu-individu tidak lagi memiliki kekerabatan di antara mereka dan juga hubungan kasih sayang. Pada akhirnya, masyarakat akan tercerai-berai dan kebahagiaan dunia dan akhirat mereka akan binasa (http://www.taqrib.info/indonesia).

Baiknya kita simak ketentuan Illahi yang berkaitan dengan perintah untuk membentuk keturunan yang kuat dan memperlakukan keturunan dengan dasar kearifan, kasih sayang dan saling berkomunikasi dengan baik. Q.S. an-Nisa: 9 


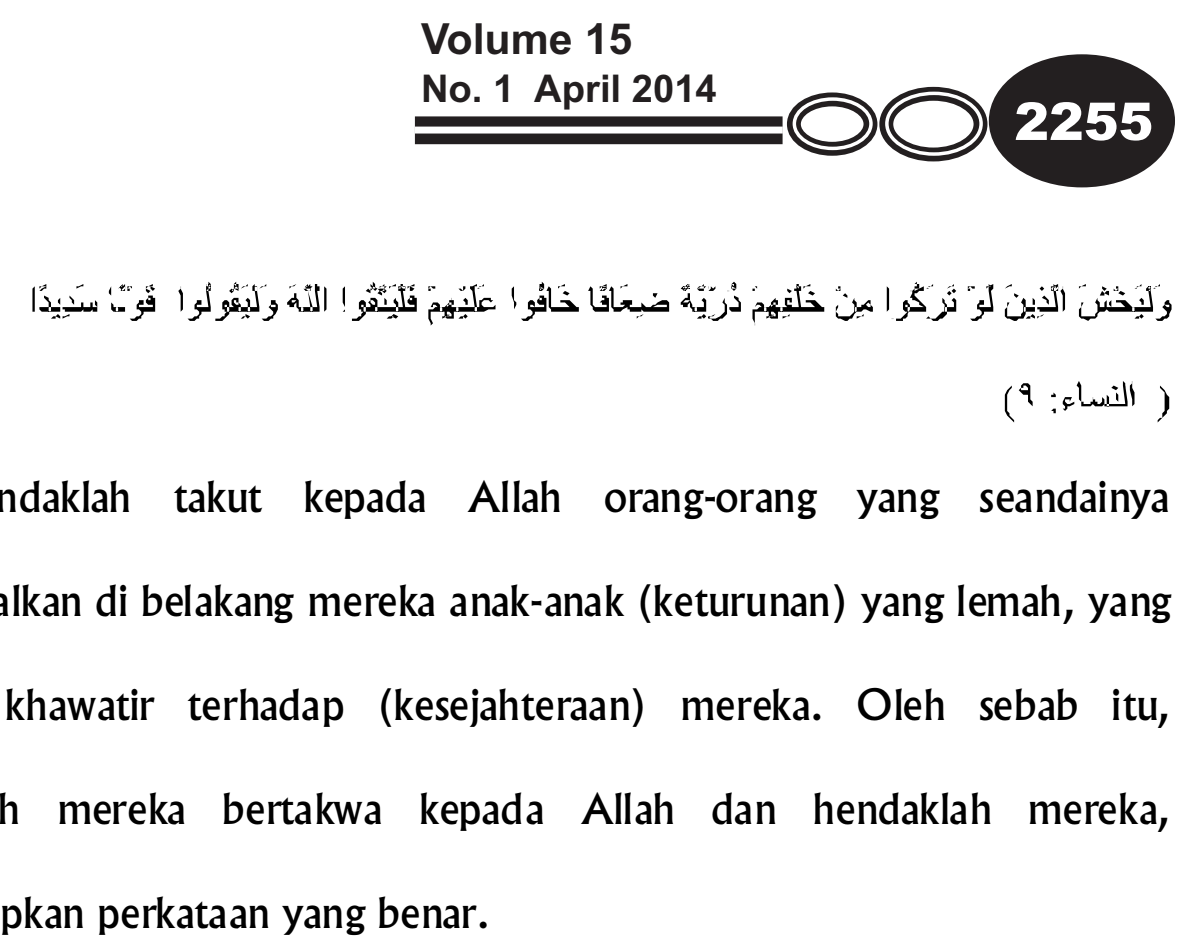

Surat ke-4 ayat 9 tersebut menjelaskan fungsi keluarga, yaitu menjaga kelangsungan hidup keluarga dari kepunahan dengan cara menyiapkan generasi penerus yang lebih kuat, baik fisik maupun mentalnya. Dari segi fisik, mereka harus dibekali dengan makanan dan minuman yang bergizi, selain sandang, pangan dan perumahan yang memadai. Sedangkan dari segi mental, mereka harus dibekali dengan pendidikan agama yang dapat menuntun mereka kepada jalan yang benar. Akhir ayat itu pun menganjurkan kepada para orang tua untuk memperlakukan semua anggota keluarganya dengan tegur sapa atau ucapan-ucapan yang baik yang menunjukkan sikap kasih sayang dan mendidik. Dengan demikian komunikasi bukan hanya formalitas, namun dibangun atas dasar kasih sayang, sehingga terdapat komunikasi yang beretika dan beradab.

Tujuan pembentukan keluarga sakinah, mawaddah, warrahmah tidak terlepas dari komunikasi yang beretika dan beradab sebagai kuncinya. 


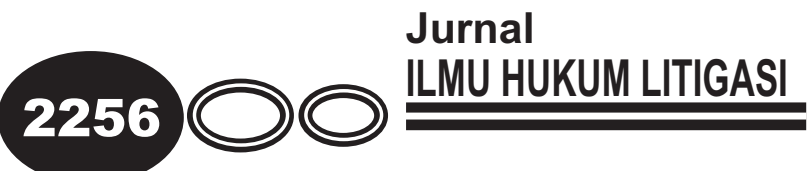

Komunikasi yang dibangun atas dasar untuk menciptakan fungsi keluarga. Meminjam istilah BKKBN (BKKBN, 2013: 12), dapat disitir 8 (delapan) fungsi keluarga, yang meliputi:

a) Fungsi agama

Keluarga sebagai tatanan sosial terkecil dalam masyarakat memiliki fungsi sebagai tempat memperkenalkan dan mengajarkan kepercayaan akan keber-Tuhan-an. Keluarga berperan untuk membentuk generasi masyarakat yang agamis, yang beriman, dan percaya terhadap keberadaan Allah Yang Maha Esa. Peran kepala keluarga (imam), orang tua mengarahkan seluruh anggotanya dan menuntunnya pada suasana kerohanian, tertanamkan dalam dirinya bahwa dipundaknya ada tanggung jawab sebagai imam untuk membawa seluruh anggota keluarganya pada jalan keselamatan dunia dan akhirat. Kepala keluarga memiliki beban yang berat dalam ini, namun akan menjadi ringan apabila untuk fungsi ini dijalankan dengan kebersamaan, dan saling mendukung. Pemberian contoh perilaku, dan komunikasi yang berbobot spiritual akan membawa seluruh anggota keluarga memiliki perannya masing-masing.

b) Fungsi sosial

Keluarga sebagai basis untuk membentuk generasi yang mengerti aturan sosial. Mengenai norma-norma yang berlaku di masyarakat, mengenai 
aturan-aturan tak baku bagaimana cara bersosialisasi terhadap sesama manusia, bagaimana menghargai alam, dan kehidupan sosial. Diharapkan anak-anak, sebagai generasi penerus dari sebuah keluarga, diberikan pendidikan mengenai tingkah laku sesuai dengan fase perkembangan mereka.

c) Fungsi cinta kasih

Dalam satu keluarga, diharapkan akan saling memberikan perhatian dan kasih sayang. Dengan berlimpahnya kasih sayang, diharapkan akan terbentuk manusia-manusia yang memiliki kecerdasan emosional, sehingga tercipta keluarga yang berkualitas, dan seterusnya akan terbentuk generasi-generasi yang berkualitas sehingga akan menciptakan suasana yang nyaman dalam sebuah kehidupan bermasyarakat.

d) Fungsi perlindungan

Keluarga menjadi satu tempat yang memberikan perlindungan yang nyaman bagi anggotanya. Melindungi setiap anggotanya dari tindakantindakan yang kurang baik, sehingga anggota keluarga merasa nyaman dan terlindung dari hal-hal yang tidak menyenangkan.

e) Fungsi ekonomi

Fungsi ekonomi yang berkaitan dengan fungsi lain yang tidak dapat dipisahkan dari sebuah keluarga. Fungsi ini dilakukan dengan cara mencari sumber - sumber penghasilan untuk memenuhi kebutuhan 


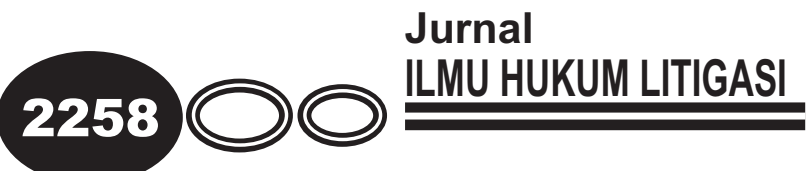

keluarga, pengaturan penggunaan penghasilan keluarga untuk memenuhi kebutuhan keluarga, dan menabung untuk memenuhi kebutuhan keluarga di masa datang.

f) Fungsi pendidikan

Keluarga sebagai tempat pendidikan pertama bagi anak-anak generasi penerusnya. Sebuah keluarga idealnya mampu menjadi tempat dimana terjadi interaksi yang mendidik. Suami terhadap istri, atau orang tua terhadap anak-anaknya. Memberikan pendidikan pada anak-anak sesuai dengan tahapan usia adalah salah satu fungsi pendidikan dalam sebuah keluarga.

Fungsi pendidikan ini dapat diaplikasikan dengan cara menyekolahkan anak-anaknya sesuai dengan perkembangan usia. Diharapkan, dengan diberikan pendidikan melalui sekolah, anak-anak akan memiliki pengetahuan, keterampilan, dan perkembangan tingkah laku sesuai dengan bakat dan minat yang dimilikinya.

Pendidikan juga dilakukan di dalam rumah, dapat dilakukan dengan memberikan contoh, mengajarkan etika, budi pekerti, dan aktualisasi pribadi dengan nilai-nilai agama.

g) Fungsi pelestarian lingkungan

Seperti fungsi-fungsi lainnya, fungsi pelestarian lingkungan merupakan satu dari delapan fungsi keluarga. Dalam fungsi ini, keluarga 
memberikan pengetahuan mengenai norma terhadap lingkungan, sehingga diharapkan generasi penerus keluarga tersebut akan lebih santun terhadap alam dan lingkungan sosialnya.

h) Fungsi reproduksi

Fungsi ini merupakan fungsi yang paling hakiki dalam sebuah keluarga karena harus dapat melanjutkan keturunannya dan yang diharapkan adalah keturunan yang berkualitas. Memelihara, membesarkan anak, dan merawat keluarga juga termasuk dalam fungsi reproduksi ini.

Pemimpin itu adalah manusia yang lahir dari keluarga. Oleh karena itu, melihat pemimpin yang baik, lihatlah dari cikal bakal keluarganya. Bagaimanakah dia memperlakukan keluarganya, bagaimana menempatkan keluarganya, apakah dalam berkeluarganya menerapkan fungsi-fungsi keluarga dengan baik, apakah dia menjunjung tinggi keluarga, apakah visi, misinya adalah menyelematkan dirinya dan keluarga untuk kebahagiaan dunia dan akhirat, maka secara nalar bekal dalam berkeluarga akan diterapkan terhadap kepemimpinannya kepada kepemimpinan umat yang lebih besar, yaitu pemimpin bangsa dalam suatu negara. Oleh karena itu, calon legislatif sebaiknya dan seharusnya lahir dari keluarga yang sakinah dan mawaddah. Visi dan misinya adalah AI-Qur'an yang menjadi hukum illahiah dalam berkeluarga, berbangsa dan bernegara. 


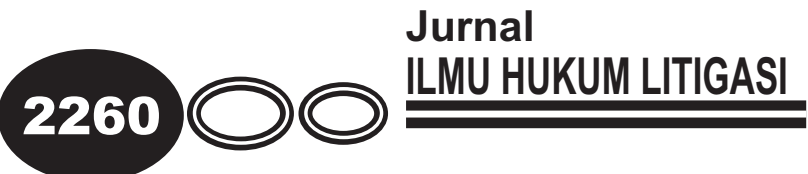

Pimpinan yang efektif, seorang pemimpin yang mampu menggunakan kewenangan yang ada padanya secara baik dan konstruktif, pemimpin yang mampu merumuskan sasaran yang jelas dan dapat dicapai berdasarkan kemampuan sumber daya yang dimiliki, pemimpin yang mampu mengkomunikasikan kepada bawahannya apa yang dipikirkan, pemimpin yang arif, dimana dalam menghadapi dan memecahkan persoalan selalu mengedepankan rasio dengan tetap mempertimbangkan rasa. Tegasnya pemimpin yang efektif itu adalah seorang pemimpin yang secara kuat memperjuangkan idealisme yang ingin dicapai. Sesungguhnya kepemimpinan efektif itu merupakan implementasi kreatif dari prinsip dan nilai-nilai Islam. Mengapa tidak, jika kita perhatikan semangat dari seorang pemimpin yang efektif, maka selamanya ia senantiasa mengedepankan prinsip-prinsip atau nilai-nilai kerja sama, kerja keras, cerdas dan memiliki kearifan, kreatif, inovatif, efektif, efisien, transpormatif, komunikatif, dan teladan. Nilai-nilai atau prinsip-prinsip tersebut paling tidak dari perspektif Islam memiliki hujjah, artinya argumentasi yang valid, sehingga dihasilkan kesimpulan yang dapat diyakini dan dipertanggungjawabkan akan kebenarannya, yang kuat untuk menjadi landasan implementatif dalam berinisiatif dan bekerja secara efektif. 
3. Keluarga Sebagai Cikal Bakal Pembentukan Integritas Moral-Spiritual, Ahklak dan Kepribadian

Dalam surat Ibrahim ayat 24-26, Allah SWT berfirman: “Tidakkah engkau perhatikan bagaimana Allah membuat perumpamaan kalimat yang baik seperti pohon yang baik, akarnya kokoh dan cabangnya (menjulang) ke langit. Pohon itu memberikan buahnya pada setiap musim dengan izin Tuhannya. Allah membuat perumpamaan-perumpamaan itu untuk manusia supaya mereka selalu ingat. Dan perumpamaan kalimat yang buruk seperti pohon yang buruk pula, yang telah dicabut akarakarnya dari permukaan bumi; tidak dapat tetap (tegak) sedikitpun".

Silsilah yang suci ini memberikan gambaran yang jelas bahwa risalah Ilahiah ini tidak pernah keluar dari lingkaran keluarga yang menempatkan kedudukan sosial dan peribadahan paling tinggi diantara aktivitas untuk beramal. Betapa tidak, dinyatakan bahwa aktualisasi amal ibadah di dunia dua pertiganya ada pada berkeluarga. Jadi, menjadi legislatif itu ada pada sekian presen saja dari sepertiga beribadah dalam berkeluarga. Oleh karena itu, ketika menjalankan tugas sebagai elit politik maka berakar dan berangkatlah dari kesakinahan, mawaddah dalam berkeluarga. Insyaallah, keluarga dan bangsa terselamatkan. Ketentraman dalam keluarga akan membawa etos kerja yang maksimal dan tumbuh berkembang menjadi pembenahan yang menyeluruh. 


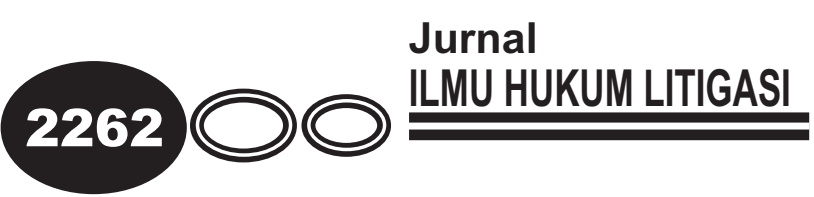

Pada keluarga yang kokoh akidah, akhlak, dan kepribadiannya akan terbentuk cikal bakal pemimpin yang berintegritas moral spiritual. Ajaran Rasulullah sebagaimana diterangkan dalam hadist, Rasul menekankan bahwa pemilihan washi telah berlaku bagi keluarga nabi dan keturunannya yang saleh dengan tujuan untuk menjaga kesucian risalah. Oleh karena itu, bagaimana mungkin ajaran Muhammad Saw yang kekal tidak membutuhkan pribadi-pribadi suci dari keturunannya yang akan menjaga nilai-nilai ajaran Illahi dari usaha penyimpangan.

Masalah pemilihan atau seleksi pelanjut kepemimpinan Illahiah adalah semata-mata wewenang Dzat yang Maha Mengetahui, tanpa adanya campur tangan siapapun. Harus dipahami dan diimani bahwa segala takdir Allah itu tercatat dalam lautzu Mahfudz (buku catatan kehidupan), dengan demikian upaya lahir dilakukan, Allah yang akan mentakdirkan. Oleh karena itu, politik wani piro, politik uang, politik janji-janji menjadikan elit politik seakan kehilangan integritas moral spiritual tentang keimanannya pada takdir. Selain itu integritas moral dipertaruhkan demi kedudukan dunia saja tanpa memperhitungkan kemaslahatan di akhirat. Pembohongan dan pendzoliman publik, masyarakat memilih orang-orang kepercayaannya karena trust, melihat integritasnya, ternyata suara kepercayaan rakyat tersebut dapat dijual dan dibeli mungkin saja oleh orang-orang yang tidak memiliki integritas yang sesuai harapan pemilih. Patut disayangkan, 
ditempatkan dimanakah kepercayaan masyrakat yang berharap ada pembangunan materil spiritual. Inilah bentuk potret kekecewaan masyarakat terhadap nilai degradasi moral spirual para elit politik calon legislatif.

Dalam Al-Qur'an surat Fathir Ayat 32 dinyatakan bahwa, "kemudian Kitab itu Kami wariskan kepada orang-orang yang Kami pilih di antara hamba-hamba Kami". Ayat ini menunjukan bahwa hamba yang dipilih sangat ketat parameternya, yang dipilih adalah orang pilihan Allah karena keimanan pada takdir, mendapat keridhoan Allah, yaitu yang dapat membawa tegaknya akidah, menyelamatkan masyarakat, bangsa dan negara baik dunia maupun di akhirat. Parameternya, tentu saja adalah orang yang memiliki kapabilitas, kredibilitas, dan akseptabilitas. Parameter tersebut diawali dari aktualisasi diri dari memimpin dalam keluarganya.

Kapabilitas dalam berkeluarga adalah kemampuan sebagai imam, sebagai pemimpin dalam menata visi, misi, dan strategi serta dalam mengembangkan sumber-sumber daya manusia, yaitu anggota keluarga (anak dan istri) yang dipimpinnya untuk bersama-sama menjadikan rumah tangga atau berkeluarga tersebut sebagai jalan untuk ibadah, imam yang mampu membawa pada keselamatan dunia dan akhirat. Kemampuan untuk memberikan ketentraman lahir dan bathin bagi seluruh anggota keluarga. Kapabilitas dalam berkeluarga tersebut akan mengakar dan 


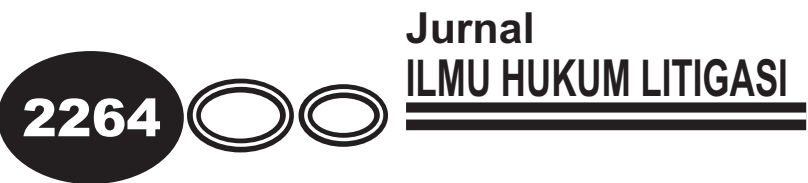

menumbuhkembangkan bagaimana seorang legislatif untuk kepentingan memajukan organisasi partainya dan atau memajukan negara, mengayomi dan memberikan ketentraman bagi rakyatnya. Kapabel, yakni mampu, sanggup, cakap, pandai. Dia adalah sosok yang memiliki kemampuan dalam memimpin, menjadi problem solver, cakap dan cerdas dalam memecahkan masalah bagi rakyat (umat) nya. (http://salam-online.com).

Kredibilitas dalam berkeluarga, adalah ciri-ciri yang ada pada seorang pemimpin (imam) seperti kompetensi-kompetensi, sifat- sifat, nilai-nilai dan kebiasaan-kebiasaan yang dapat dipercaya oleh anggota keluarga, yaitu terhadap istri dan anak-anaknya atau anggota keluarga yang lain. Akar yang dibina dari keluarga yang harmonis maka akan sangat mudah dan elegan diterapkan pada skala yang lebih besar, yaitu dalam memimpin bawahan atau lingkungannya, atau dalam memimpin bangsa.

Kredibilitas pribadi yang ditampilkan pemimpin yang menunjukkan kompetensi seperti mempunyai kekuatan keahlian (expert power), selain adanya sifat-sifat, nilai-nilai dan kebiasaan-kebiasaan yang positif (moral character) apabila dipadukan dengan kemampuan pemimpin dalam menata visi, misi, dan strategi organisasi/ wilayah yang jelas akan merupakan suatu kekuatan dalam menjalankan roda partai, yang berimbas pada pencapaian tujuan negara kesejahteraan. 
Menjadi anggota legislatif bukan sekedar keterpilihannya untuk duduk di kursi DPR, akan tetapi merupakan akseptabilitas yang bersangkutan karena diterima oleh masyarakat. Jika seseorang terpilih menjadi anggota legislatif bukan hanya diterima secara hukum, akan tetapi juga diterima oleh masyarakat. Seorang pemimpin tidak cukup sekedar memiliki kredibilitas dan kapabilitas. Keduanya tak punya arti apa-apa, kalau tak didukung dan diterima masyarakat dan banyak pihak dari berbagai kalangan. Akseptabilitas pemimpin itu sangat bergantung dari kredibilitas dan kapabilitasnya. Artinya, akseptabilitas dengan sendirinya didapat, jika kredibilitas dan kapabilitas dimiliki. Miris rasanya ketika saat ini, menjadi keinginan untuk menjadi anggota legislatif dengan menggunakan berbagai cara, bahkan sampai dengan cara yang tidak halal.

Perlu disikapi bahwa akseptabilitas dari calon legislatif harus bersumber dari keluarga. Sebab, keluarga adalah orang-orang yang dapat menilai secara hakiki dan objektif tentang kredibilitas dan kapasitasnya sebagai imam. Bagaimana mungkin seorang calon legislatif dapat memimpin suatu umat/bangsa yang besar jika tidak memiliki kredibilitas dan kapasitas sebagai imam dalam memimpin unit terkecil yaitu keluarganya. Akseptabilitas keluarga dapat dinilai dari apakah seorang mendapatkan ijin dari anggota keluarga, yang mana ini sering dilupakan. Bermusyawarah dan bermufakat dengan anggota keluarga dalam 


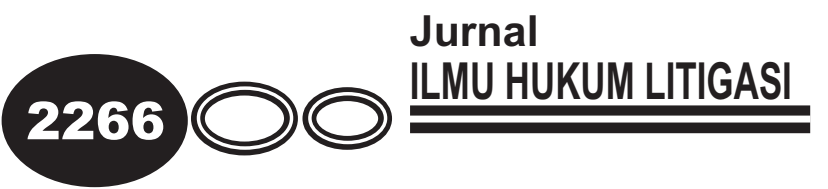

menentukan kiprah untuk menjadi calon legislatif banyak diabaikan calon anggota legislatif. Oleh karena itu, sering menjadi tarik menarik antara egoism, hedonism dan evoria para calon legislatif. Meniadakan peran anggota keluarga yang menjadi cikal bakalnya. Banyak disaksikan dalam faktanya, jika sudah menjadi anggota legislatif rumah tangganya berantakan, perceraian terjadi, pembiaran dan penelataran secara psikologis terhadap anggota keluarga. Bahkan hal itu dapat terjadi, ketika masa konsolidasi dengan masyarakat, sosialisasi, kampanye para calon legislatif sering melupakan bahwa dia berkeluarga. Hal ini karena didorong oleh keambisiusannya, dan dianggap prestise. Padahal, keluarga ujung tombak pembinaan kepemimpinannya. Sebaiknya seorang pemimpin dalam kiprahnya harus bersumber dari keluarga, berproses dari dan dalam berkeluarga, dan akhirnya bermuara pada keluarga, baik berkeluarga dalam unit terkecil yang menjadikannya keluarga dalam scope bangsa, dan tidak melupakan unit keluarga terkecil yaitu rumah tangganya sebagai cikal bakal pembentukkan kepemimpinannya. Kasus anggota DPR Komisi III, Hotman Sitompul patut dijadikan inspirasi, yang mana dengan elegan istrinya menyatakan keberatan apabila suaminya menjadi ketua komisi III, adalah patut menjadi kajian, betapa akseptabilitas dari keluarga menjadi suatu hal yang seharusnya diperhitungkan. Kasus ini akan menjadi preseden yang baik. Wacananya, ke depan untuk menumbuhkan nilai-nilai 
kepemimpinan yang efektif sebaiknya ijin, pernyataan dari anggota keluarga terutama istri atau anak-anak yang sudah dewasa menjadi persyaratan menentukan diterimanya pendaftar calon legislatif. Selain itu, untuk menilai integritas moral spiritual, akhlak dan kepribadian sebaiknya ada komitmen bahwa para calon legislatif harus dapat membina keluarga yang harmonis, dengan ditandatangani oleh seluruh anggota keluarga inti. Hal ini bertujuan membangun bangsa yang lebih maju berakar dari keluarga yang sakinah menjadi kokoh dan berakar.

Akseptabilitasi ini mengkritisi keambisiusan seseorang untuk menjadi calon legislatif, dengan strategi politik uang, jual beli suara, dan manipulasi suara selama masa rekapitulasi. Politik uang atau politik perut, adalah suatu bentuk pemberian atau janji menyuap seseorang baik supaya orang itu tidak menjalankan haknya untuk memilih maupun supaya ia menjalankan haknya dengan cara tertentu pada saat pemilihan umum. Pembelian dapat dilakukan menggunakan uang atau barang. Politik uang adalah sebuah bentuk pelanggaran kampanye. Politik uang umumnya dilakukan simpatisan, kader atau bahkan pengurus partai politik menjelang hari $\mathrm{H}$ pemilihan umum. Praktik politik uang dilakukan dengan cara pemberian berbentuk uang, sembako antara lain beras, minyak dan gula kepada masyarakat dengan tujuan untuk menarik simpati masyarakat agar 


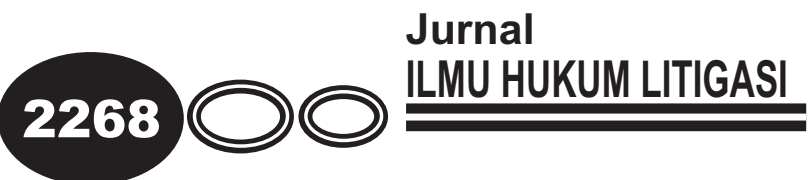

mereka memberikan suaranya untuk partai yang bersangkutan. (Wikipedia: org/wiki/Politik_uang)

Pasal 73 ayat 3 Undang Undang No. 3 Tahun 1999 menyatakan bahwa:

"Barang siapa pada waktu diselenggarakannya pemilihan umum menurut undang-undang ini dengan pemberian atau janji menyuap seseorang, baik supaya orang itu tidak menjalankan haknya untuk memilih maupun supaya ia menjalankan haknya dengan cara tertentu, dipidana dengan pidana hukuman penjara paling lama tiga tahun. Pidana itu dikenakan juga kepada pemilih yang menerima suap berupa pemberian atau janji berbuat sesuatu."

Jual beli suara dalam pemilu. Modus (1) Transaksi suara di antara caleg di parpol yang sama. "Sangat mungkin suara caleg dicurangi oleh rekannya sesama caleg satu parpol, Modus (2) terjadi jual beli suara antarparpol. Parpol bisa membeli suara dari parpol lain yang tak mungkin mendapatkan kursi legislatif. Jual beli suara seperti ini memungkinkan parpol yang seharusnya mendapatkan kursi legislatif, kehilangan kesempatan karena dicurangi parpol lain yang telah melakukan transaksi jual beli suara.

B. Sikap Cerdas Masyarakat Pemilih Terhadap Calon Pemimpin yang Tidak Berkomitmen Kepada Keluarga

Kecintaan seorang pemimpin terhadap keluarga unit terkecilnya, memiliki kedudukan yang sama dengan kecintaan Rasulullah terhadap Ahlul Baitnya. Keluarga merupakan amanah Allah SWT bagi imamnya, yaitu kepala 
keluarga. Dan imam pada skala yang lebih besar yaitu imam (elit politik kenegaraan) memiliki amanah untuk membawa makmum (rakyat) selamat di dunia dan akhirat. Pemimpin yang menjunjung tinggi kemulian keluarga, nilainilai berkeluarga berakar terhadap memimpin umat. Tentunya ruh dari nilainilai itu berasal dari kitabullah ( $\mathrm{Al}-\mathrm{Qur}$ an). Demikian dapat dimaknai amanah Rasulullah sebagai berikut, "Sesungguhnya aku telah tinggalkan kepada kalian tsaqalain (dua peninggalan yang sangat berharga) yang salah satu dari keduanya lebih besar daripada yang lain, Kitabullah (AI-Qur'an) dan keturunanku (keluarga). Oleh karena itu perhatikanlah oleh kalian dalam memperlakukan keduanya sepeninggalku. Sebab sesungguhnya keduanya tidak akan pernah berpisah, sehingga berjumpa denganku di Haudh (Mutawalli Sya"rawi, Mohammad, 2010: 57). Apabila umat Islam bershalawat, bukan berarti umat memohon keselamatan untuk Rasulnya, karena tidak dimohonkanpun Rasullullah telah menjadi manusia pilihan yang diselamatkan Allah. Shalawat harus dimaknai bahwa kecintaan umat kepada nabi dan A hlul Baitnya bukan sekedar cinta biasa, bukan sekedar efek dari kecintaan kepada Nabi SAW, bukan pilihan melainkan kewajiban yang telah menjadi bagian dari syariat agama karena Ahlul Bait yang menjadi generasi penerus haruslah yang menjaga kemurnian risalah Illahi. Oleh karena itu, kecintaan kita kepada keluarga adalah juga kecintaan kepada Rasulullah SAW, kecintaan kepada Allah SWT, kecintaan kepada Islam dan agama ini. 


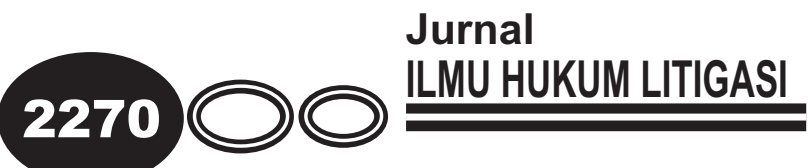

Penghormatan dan menjunjung tinggi nilai-nilai berkeluarga merupakan titah yang digariskan syariat Islam.

Perlu dikritis, bagaimanakah apabila seorang caleg, dari sisi integritas berkeluarganya dipertanyakan? Hal yang sudah lazim, waktu, biaya, tenaga, pikiran tercurahkan untuk upaya pemenangannya, lupa bahwa takdir ada di tangan kuasa-Nya. Keluarga ditiadakan, bahkan tidak mustahil keluarga tidak dilibatkan dalam hal pencalonannya. Dalam proses sosialisasi, waktu untuk keluarga-pun tidak ada. Bahkan, untuk biaya kampanye bisa menghabiskan rumah tempat bernaung keluarga dijual. Dalam kondisi ini para caleg kehilangan jati diri berkeluarga, dan dzolim terhadap anggota keluarganya, karena tanpa perhitungan dan iman kepada takdir, bahkan ada yang sampai berkonsolidasi dengan memanfaatkan kedekatan dengan lawan jenis, sehingga terjadi konspirasi hati, maka timbulkan kehancuran keluarga intinya. Agama tidak lagi menjadi pedoman baginya. Sebagai pemilih yang cerdas, tentulah harus punya sikap.

1. Qs. Al-An'am: 70

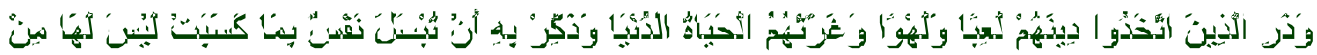

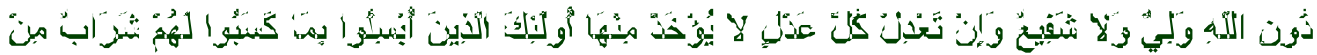

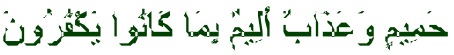

Dan tinggalkan lah orang-orang yang menjadikan agama mereka sebagai main-main dan senda gurau, dan mereka telah ditipu oleh kehidupan 
dunia. Peringatkanlah (mereka) dengan Al-Quran itu agar masing-masing diri tidak dijerumuskan ke dalam neraka, karena perbuatannya sendiri tidak akan ada baginya pelindung dan tidak pula pemberi syafa'at selain daripada Allah dan jika ia menebus dengan segala macam tebusanpun, niscaya tidak akan diterima itu daripadanya. mereka itulah orang-orang yang dijerumuskan ke dalam neraka, bagi mereka (disediakan) minuman dari air yang sedang mendidih dan azab yang pedih disebabkan kekafiran mereka dahulu.

2. QS. An-Nisa: 36

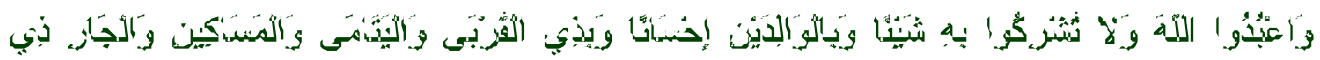

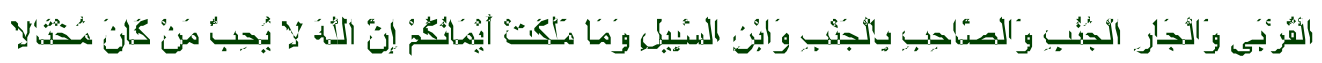
(5)

Sembahlah Allah dan janganlah kamu mempersekutukan-Nya dengan sesuatupun, dan berbuat baiklah kepada dua orang ibu-bapa, keluargakerabat, anak-anak yatim, orang-orang miskin, tetangga yang dekat dan tetangga yang jauh, dan teman sejawat, Ibnu sabil dan hamba sahayamu. Sesungguhnya Allah tidak menyukai orang-orang yang sombong dan membangga-banggakan diri. 


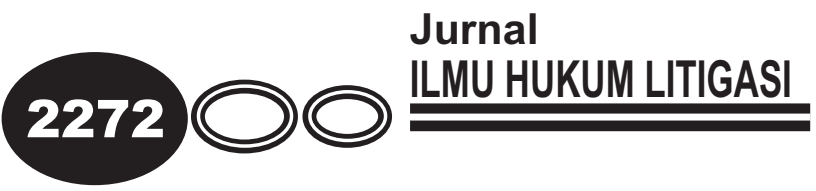

3. QS. Huud: 117-119

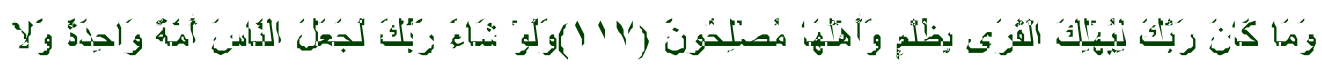

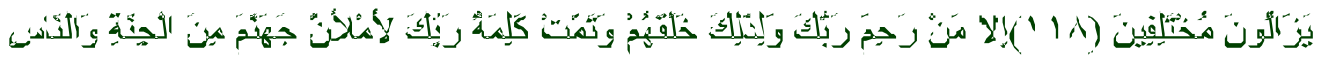

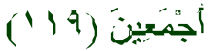

Dan Tuhanmu sekali-kali tidak akan membinasakan negeri-negeri secara zalim, sedang penduduknya orang-orang yang berbuat kebaikan. Jikalau Tuhanmu menghendaki, tentu Dia menjadikan manusia umat yang satu, tetapi mereka senantiasa berselisih pendapat, kecuali orang-orang yang diberi rahmat oleh Tuhanmu, dan untuk itulah Allah menciptakan mereka. Kalimat Tuhanmu (keputusan-Nya) telah ditetapkan: Sesungguhnya aku akan memenuhi neraka Jahannam dengan jin dan manusia (yang durhaka) semuanya.

\section{SIMPULAN DAN SARAN}

\section{A. Simpulan}

1. Kelestarian generasi umat manusia tergantung pada eksistensi keluarga yang dibangun atas dasar mawaddah dan rahmah. Dengan melemahnya pilar-pilar berkeluarga pada akhirnya akan menceraiberaikan kelanggengan dan kebahagiaan masyarakat baik dunia maupun akhirat. Keluarga ibarat pohon, jika akamya sehat dan kokoh, maka batangnya akan menjulang tinggi dan akan menghasilkan buah yang berkualitas, 
keluargalah akar itu. Pemimpin berawal dan tumbuh dalam keluarga. Nilai-nilai dalam berkeluarga menjadi parameter integritas moral spiritual, akhlak dan kepribadian seorang pemimpin. Kapabilitas pemimpin dalam suatu keluarga adalah kemampuan sebagai imam dalam membuat, menata, dan melaksanakan visi, misi, dan strategi dalam membawa dan mengembangkan sumber-sumber daya manusia yaitu anggota keluarganya (anak, istri, dan sanak keluarga) yang dipimpinnya untuk bersama-sama membangun rumah tangga yang bertujuan meraih selamat dunia akhirat. Kepemimpinan Islam adalah kepemimpinan yang berdasarkan hukum Allah. Oleh karena itu, pemimpin haruslah orang yang sarat dengan pengetahuan tentang hukum Illahi, aktivitas kesehariannya berpedoman kepada hukum Illahi dalam bentuk aktualitas diri, dan memiliki komitmen tanggung jawab, dengan jaminan menyelamatkan kaum/bangsa baik dunia maupun akhirat. Dengan demikian apabila nilai-nilai dalam kepemimpinan Islam dalam berkeluarga dijadikan oleh para elit politik, calon legislatif, atau yang sudah menjadi legislatif ditegakkan, diyakini bahwa negara Indonesia akan terbebas dari kemelut komitmen politik yang ewuh pakewuh, politik wani piro, komitmen politik yang menyebabkan seorang elit politik menjadi tinggi hati, sombong, ria takabur, dan tidak memiliki jati diri. Integritas moral dipertaruhkan demi kedudukan dunia saja tanpa memperhitungkan kemaslahatan di akhirat. 


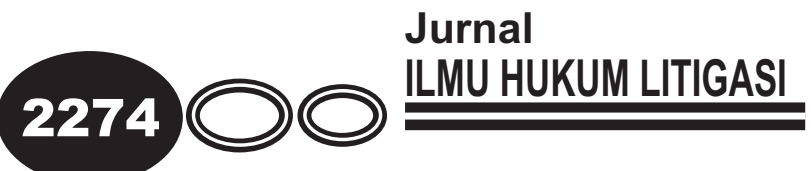

Terjadi marak pembohongan dan pendzoliman publik. Inilah bentuk potret degradasi moral spiritual para elit politik calon legislatif.

2. Seorang pemimpin bangsa atau umat cikal bakalnya dari keluarga, dan keluarga ibarat pohon, seorang pemimpin ibarat akarnya, jika pemimpinnya kokoh, maka bangunan rumah tangga berkeluarga dan bernegara akan terjunjung tinggi, dan menghasilkan buah generasi penerus yang berkualitas. Pemimpin yang berakar integritasnya dari nilainilai Islam dalam berkeluarga menjadi parameter integritas moral spiritual, akhlak dan kepribadian seorang pemimpin bangsa. Seorang pemimpin yang bernilai di mata dan hati masyarakat/bangsa adalah pemimpin dimata hati keluarganya. Visi misi pemimpin untuk bangsa dan keluarga pada dasarnya, yaitu menyelamatkan diri dan keluarganya, menyelamatkan dirinya dan umatnya dengan menegakkan hukum. Fenomena yang marak terjadi saat ini dalam keinginan berlegislatif akan tetap berlanjut bergantung pada harapan masa depan diri, keluarga, masyarakat, dan negara. 
B. Saran

Jadilah pemilih yang cerdas, sebaiknya pilihan didasarkan pada penilaian integritas moral spiritual, akhlak dan kepribadian para calon pemimpin yang berkomitmen dan menjunjung tinggi nilai-nilai berkeluarga. Semoga negeri ini dijauhkan dari kedzoliman pemimpin. Semoga pemimpin khususnya anggota legislatif Indonesia ke depan memiliki visi, misi, dan langkah nyata menyelamatkan diri, keluarga, dan umat ini dengan menegakkan hukum. Amiiin.

\section{DAFTAR PUSTAKA}

Aam, Amiruddin, 2005, Tafsir Al-Qur'an Kontemporer, Bandung, Khasanah Intelektual.

Arvan, Pradiansyah, 2008, Manajemen Kepemimpinan Muhammad, Bandung, Mizan Pustaka.

Effendi, 1992, Kepemimpinan dan Komunikasi, Bandung, Mandar Maju.

Hadari, Nawawi, 2001, Kepemimpinan Menurut Islam, Jakarta, GMUP.

Hisham, Yahya Altalib, 2003, Kepemimpinan Islam, Pustaka Hidayah, Bandung.

Mohammad, Mutawalli Sya"rawi, 2010, Untaian Kisah-Kisah Qur'ani Dalam Surat Al-Kahfi, Jakarta, Yayasan Alumni Timur Tengah.

Muhammad, Daud Ali, 2005, Hukum Islam: Pengantar Ilmu Hukum Dan Tata Hukum Islam Di Indonesia, Jakarta, Raja Grafindo Persada. 


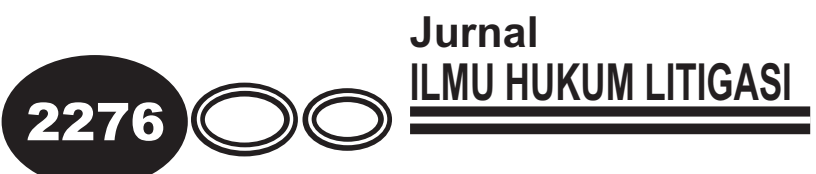

Muhammad, Muhyidin, 2006, Nggak Kaya Duit Asal Kaya Hati: Menyikap Misteri Kekuatan Hati Bagi Kecerdasan Spritual Dan Finansial, Jogyakarta, Tunas Publishing.

M Quraish, Shihab, 2007, Pengantin Al-Qur'an, Tangerang, Lentera Hati.

-----, 2008, Berbisnis Dengan Allah, Tangerang, Lentera Hati.

Nurul, Aina, 2008, Belahan Jiwa Muhammad SAW, Bandung, Arkan Publishing.

R. Terry, George, 2006, Manajemen, Jakarta, Bumi Aksara.

Sulaiman, Rasjid, 1998, Fiqh Islam, Bandung, Sinar Maju.

Sulistyowati, Irianto, 2006, Perempuan Dan Hukum, Jakarta, Yayasan Obor Indonesia.

Tobroni, 2010, The Spritual Leadership, Tangerang, Lentera Hati.

W.A. Garungan, 1967, Psikologi Sosial, Bandung, PT. Eresco.

\section{JURNAL}

Boediono, 2013, Nilai Luhur Kemanusiaan Lahir Dari Keluarga, Warta Kencana, Vol XX. Edisi Khusus.

Ismail Tuanany, 2009, implementasi-nilai-nilai-islam-dalam-kepemimpinan-efektif, Jurnal Tahlim, Vol. 11 No.5. 


\section{MAKALAH}

Sudibyo Alimoeso, Membangun Keluarga Indonesia, Disampaikan Dalam Seminar Sehari Membangun Keluarga Indonesia, yang diselenggarakan BKKBN dengan PPKS Kencana Pasundan, Bandung, 18 Desember 2013.

\section{WEBSITE}

Ismail Amin, Mengapa kita harus mencintai ahlul baith, http://indonesian.irib.ir/artikel1/asset_publisher/7xTQ/content/mengapakita-harus-mencintai-ahlul-bait-nabi/pop_up, Posted.

Ismail Tuanany, Implementasi Nilai-nilai Islam dalam Kepemimpinan Efektifhttp://jurnaltahkim.wordpress.com/2009/05/11/implementasi-nilai-nilaiislam-dalam-kepemimpinan-efektif/, Posted 11 Mei 2009.

Salam, pemimpin-yang-kredibel-kapabel-dan-akseptabel, http://salamonline.com/2012/07/sulitnya-mencari-pemimpin-yang-kredibel-kapabel-danakseptabel.html\#sthash.gQDiSZ2V.dpuf, Posted.

Sayyid Eshaq Hosseini Kohsari, Kedudukan Keluarga Dalam Islam, http://www.taqrib.info/indonesia/, Posted.

Suliadi RS, Pemimpin dan Kepemimpinan Dalam Islam, http://berkarya.um.ac.id/2011/05/01/pemimpinan-dan-kepemimpinanmenurut-islam/, Posted 01 Mei 2011. wikipedia.org/wiki/Politik_uang. 